\title{
German Universities as Actors in Organizational Design - A Qualitative Study
}

\section{Ilse Hagerer, Uwe Hoppe}

School of Business Administration and Economics, Osnabrueck University, Germany.

\begin{abstract}
After the latest reforms in higher education according to the NPM (New Public Management), the autonomy of universities and the organizational perspective have been strengthened. According to predominantly used neoinstitutional research in higher education, organizations adapt their structure by the pressure of legitimacy from outside. So the research question arises if universities are actors and if so, what are the influencing factors on organizational structure. The goal is to point out the reasons for organizational design and if they act on their own or only adapt changes by pressure from outside. For this, interviews with 16 experts in faculty management are conducted and interpreted using qualitative content analysis according to Mayring and Grounded Theory.

The results show that it is possible for faculties to change and design their organizational structures. There is staff responsible for this task. They work in the faculty between management and administration. Reasons to change the organizational structure are not caused by legitimacy. Much more, the new tasks cause a real need for new positions. This argumentation is not in line with neo-institutionalism. So the results strengthen the thesis that neoinstitutionalism is not sufficient anymore to explain the organizational change of universities.
\end{abstract}

Keywords: Higher education organization; new public management; organizational design; qualitative research; neo-institutionalism. 


\section{Introduction}

Reforms in higher education according to the NPM and Bologna have caused profound organizational changes. They emphasize the increasing economic rationality of the university (Christensen, 2011). The autonomy of higher education institutions has been strengthened in most higher education systems. They are seen more and more as service companies and less as cultural institutions (Braun \& Merrien, 1999; Hüther \& Krücken, 2018, p. 135). Universities are intended to develop to complete organizations, which means that they have an identity, a hierarchical organization, in which the leadership has decisionmaking power, and rationality, which means effective and efficient acting (Brunsson \& Sahlin-Andersson, 2000).

Until now, higher education research has often used sociological neo-institutionalism to analyze the in-depth changes (Krücken \& Röbken, 2009). According to neo-institutional research, organizations adapt their structure by pressure from outside (isomorphism caused by legitimacy). The organizational structure is defined as the system of rules to adjust the behavior of the members of the organization to a specific superordinate goal (Frese, 1992, pp. 1670-1671). The organizational design focuses on adapting the existing organizational structure to changing requirements (Scherm \& Pietsch, 2007, p. 128).

The problem area of neo-institutionalist theory is the exclusion of the actor and his interests and strategic actions (Walgenbach \& Meyer, 2008, pp. 115-116). It is questioned that the idea of neo-institutionalism is still useful for recent research about higher education organization. From this, the research question arises if universities are actors and if so, what are the influencing factors on organizational structure. So, the goal of this paper is to point out the causes for organizational design, which can be interpreted here as agility drivers, and if they act on their own or only adapt changes by pressure from outside. Agility drivers mean here the ability responding to changes as described in chapter 2. For this purpose, first, a brief overview of NPM and actorhood is given as well as an overview of neoinstitutionalism in higher education research. Then, the research procedure of conducting interviews with experts and analyzing them using methods of qualitative research as grounded theory and qualitative content analysis according to Mayring is described. The results are presented, discussed with alignment into current research, and a conclusion is drawn.

\section{NPM, actorhood, and neo-institutionalism in higher education research}

In the following, the connections between the NPM and universities as organizations from higher education research are outlined. Universities are specific bureaucracies, which deviate from the rational-bureaucratic organizational model in some ways: in research, they are considered as loosely coupled systems (Weick, 1976), professional organizations 
(Mintzberg, 1983), and organized anarchies (Cohen, March, \& Olsen, 1972). These deviations restrict characteristics of bureaucracy as goal attainment, decision rationality, and hierarchical control (Hüther \& Krücken, 2018).

So far, neo-institutionalist classics are predominantly used to analyze the profound processes of change in the organization of higher education institutions caused by the NPM (Meyer \& Rowan, 1977; March \& Sutton, 1997; Delucchi, 2000; Röbken, 2004; Morphew \& Hartley, 2006; Meier, 2009; Krücken \& Röbken, 2009, p. 327; Blümel, 2016). The main components of neo-institutionalism are isomorphism, which means alignment by the assurance of legitimacy (Krücken \& Röbken, 2009). Legitimacy is derived from the environment of the organization through conformity with predominant expectations, which is expressed in the outwardly directed formal structure of the organization. The cause for organizational change and new structures, e. g. by the establishment of positions in faculty management, is therefore not to improve decision-making structures in an effective and efficient way. In earlier publications of neo-institutionalist theory, organizations seem to be passive units that adapt to the expectations of the institutional environment and adopt institutionalized structural elements and management practices (Oliver, 1991; Walgenbach $\&$ Meyer, 2008). Interests, strategic actions and the power of actors are excluded (Beckert 1999; Walgenbach, 2014, p. 329). More recent developments, however, cannot longer easily be explained by early neo-institutionalist theories due to increased efficiency expectations, privatization, and accountability obligations (Meyer \& Rowan, 2006; Krücken \& Röbken, 2009). Recent publications show that the organizational specifics of universities are relativized. Blümel (2016) states that the academic-bureaucratic model of administration is to be replaced by a post-bureaucratic management model. The NPM reforms are seen as an attempt to construct universities as "complete organizations" (Brunsson \& Sahlin-Andersson, 2000), which means that universities are aligned with companies. Complete organizations are characterized by the dimensions identity, hierarchy, and rationality. For faculties, this means shifting decision-making authority towards faculty management and e. g. the use of instruments like performance measurement and evaluations. However, this development cannot completely modify organizational peculiarities (Hüther \& Krücken, 2018). Complete organizations are called actors following the neo-institutionalist language (Brunsson \& Sahlin-Andersson, 2000; Meier, 2009).

The term organizational actorhood has gained prominence in literature about higher education. It describes the basic elements of the change processes with emphasis on organizational accountability, formalization of structures, and focus on goal definition and managerialism (Krücken \& Meier, 2006; Meier, 2009; Elken \& Røsdal, 2017). With the ability to behave like an actor, also agility comes into focus. Agility is the ability to both create and respond to change in order to profit in a turbulent business environment (Highsmith 2004), which is caused in higher education by increasing competition from 
Bologna and NPM. Sharifi and Zhang (2001) suggest that agility conceptually encompasses responding to changes in time, and exploiting and taking advantage of changes as opportunities. So, the causes for change can be interpreted as agility drivers.

\section{Method}

To gain data about organizational design, interviews with experts are suitable. The advantage of expert interviews is that they provide in-depth insights into the organizational activities of the faculties. Qualitative research is appropriate when little is known about a field of research. It has an explorative character (Vogelsang, Steinhüser, \& Hoppe, 2013; Mayring, 2014) and serves a better understanding of the phenomena to be investigated (Döring \& Bortz, 2016). Qualitative research is increasingly gaining acceptance because it makes it possible to obtain new insights (Palvia et al., 2004). Additionally, the detection of new categories, the finding of their concrete meaning in the faculty and theory formation as well as hypothesis formation are possible using qualitative research.

For this, sixteen guided interviews were conducted. Initially, thirteen of the sixteen persons were interviewed. After evaluating the results, three further experts were interviewed with unchanged guideline to prove the theoretical saturation (Strübing, 2014). As no further impulses could be gained from the new data, the data set was regarded as useful. Members of faculty management from eight universities and faculties of different disciplines within Germany were selected as experts. They hold positions as deans, heads of institute, faculty or deanery advisors, study course coordinators or managers and therefore have profound knowledge about the organizational activities. In selecting the sample, care was taken to provide diversity regarding the size of the university, the size of the faculties, the disciplines, and the federal states in order to ensure multi-perspective views and to reflect the heterogeneity of the population (Flick, 2016, p. 156). Table 1 and table 2 give information about the job titles and the disciplines of the interviewed experts. 
Table 1. Job titles of the interviewees.

\begin{tabular}{ll}
\hline Job title & Interview \\
\hline Study course coordinator & $1,2,3,4,5$ \\
Course Planning, Accreditation, Quality Management & 13 \\
Head of personnel / organizational development & 16 \\
Head of institute & 6,7 \\
Faculty advisor, deanery advisor, manager, director, administration manager & $9,10,12,13,15$ \\
Dean & 8,11 \\
\hline Total & 16 \\
\hline
\end{tabular}

Source: own research.

Table 2. Disciplines of the interviewees.

\begin{tabular}{ll}
\hline Discipline & Interview \\
\hline Economics, business administration, law & $2,3,7,8,11,13,14,15,16$ \\
Engineering, natural science & $4,9,10,12,16$ \\
Humanities, social science & $1,5,6,14,16$ \\
\hline Total & 16 \\
\hline
\end{tabular}

Source: own research.

The interviews were held with the help of a semi-structured interview guideline, including the following sections: a) Presentation of the interviewee; b) Understanding reasons to change the organizational structure, including questions like: Is there scope for organizational design and to what extent is it used? Which are the reasons to adapt the organizational structure? Can the structure be influenced at all? Is there a person responsible for organizational design in the faculty? The interviews were conducted in German and afterward translated for research purposes. They had a length of 45 minutes to 1:45 hour. Twelve of the sixteen interviews were held in a personal conversation, four by telephone. There are quality criteria for qualitative research from Steinke (1999), Kromrey, Roose, \& Strübing (2016), and Strübing et al. (2018) like reliability (Kromrey, Roose, \& Strübing, 2016, p. 321), empirical saturation (Strübing et al. 2018, p. 88), and traceability (Steinke, 1999, p. 207; Döring \& Bortz, 2016). The interviews were recorded and transcribed to provide intersubjective traceability and documentation (Steinke, 1999, p. 207). Additionally, they were coded in two iterations to provide intra-coder reliability as well as from different researchers to provide inter-coder reliability (Kromrey, Roose, \& 
Strübing, 2016, p. 321). The length of the interviews and the heterogeneity of the sample ensure empirical saturation (Strübing et al. 2018, p. 88). Further is named the role of the researcher, who should be clearly defined during the research process, so that the subjects are not influenced in their statements (Steinke, 1999, pp. 231-323), and coherence, which means consistency of statements (Steinke, 1999, pp. 241-248). The attribution of the statements proves to be clear. So, important quality criteria of qualitative research are fulfilled. The results can, therefore, be considered relevant to this field of research.

The qualitative content analysis according to Mayring (2015) is appropriate because relevant categories can be identified during the research process. The method of reducing relevant interview statements to categories is thoroughly used. The categories are founded on careful interpretation. The techniques that were provided by Mayring (2014) are combined with the techniques from Grounded Theory. The core of Grounded Theory is to enable the development of theoretical suggestions from the text material (Glaser \& Strauss, 1975). Results can be compared with those of other already existing theories after finishing the coding process. As expected in Grounded Theory (Corbin \& Strauss, 1990), it was the purpose to act as a neutral observer to receive answers from different perspectives. The results are presented and discussed in the following.

\section{Discussion}

Two categories from the interviews could be considered relevant. As the first detected category, agility drivers could be identified in the form of more complex tasks and needs. Reasons for changes in the organizational structure can be interpreted as agility drivers because they foster agility, which is defined as the ability to exploit and respond to changes in time (Sharifi and Zhang, 2001). As the second category, the existence of an organizational designer was identified. In the following, both categories are defined and explained using examples from the interview material.

An increasing amount and complexity of the tasks and needs are mentioned as agility drivers of the organizational structure. One interviewee responsible for personnel and organizational development describes the remit like this: "One of my first activities here was the reorganization of the departments into faculties. Within this framework, new positions such as faculty management were established. These are all jobs that were newly created. With these positions, one tries to establish a long-term management position next to the deans because it was clear that more and more tasks are coming up for the universities, which not only have to do with research and teaching but also with financial questions, science management, evaluation and so on. There, the university needs someone who ensures certain continuity, besides the dean, who changes every two years." (Interview 16) This increased amount of work is caused by more self-administration (Interview 12), 
more audits and accreditation obligations. This is caused by law (Interview 2, 16), the size of the faculty measured in number of students (Interview 1), and the structure of students (Interview 3, 12): a large percentage of students with a migrant background or first university graduates in their family cause a large need for advice. It is also highlighted that the Bologna reforms cause more tasks (Interview 4). Students have more demand for advice, but also their expectation attitude has increased. This leads to a higher workload for faculty management and advisory positions (Interview 4, 1). The personality of students in the sense of less independence and autonomy is, therefore, another factor influencing the workload (Interview 6,1). It is further stated that an adjustment is made in the case of a personnel change due to resources becoming available (Interview 6).

In addition, the interviewed persons confirm that organizational design is possible by an organizational designer such as the dean (who fulfils these tasks among many others in his role), managing director or faculty advisor or an employee for personnel and organizational development: "The dean takes care of the current business, and there are also somehow structural questions or administrative matters, with everything that concerns administrative, which I also manage." (Interview 13) A dean illustrates the responsibilities as follows: "The managing director also has a very important position, because, as I said, she is there every day, and she also knows where problems lie with the employees and who actually undertakes what tasks and where there is still potential for new tasks, de facto the organizational design is done by the managing director, but of course, de jure, i.e. legally, I would already have the opportunity to say that I would like to do things differently." (Interview 11) Organizational design is possible by the dean (limited by a short term of office) or new professionals like the managing director or faculty advisors. This points to the university's ability to act and to its status as an actor (Meier, 2009). By implementing management reforms, universities should develop similarities with corporate actors (Braun, 1999, p. 240; Meier, 2009). There is a need to establish new positions caused by more tasks which are provoked by law and reforms (Bologna).

\section{Conclusion}

Causes for adapting the organizational structure by creating new positions for faculty management are less to be attributed to isomorphism or legitimacy, which would have caused statements in the argumentation like "that is how it is done nowadays, it is modern", than to actual needs. In this respect, the sociological neo-institutionalism cannot explain the reasons. The explanation by the actual needs and more complex tasks rather points to the economic principle. This also shows that the change of higher education organization does not only follow external institutional demands (Levy, 2006), but speaks for a stronger actortheoretical view (Krücken \& Röbken, 2009; Walgenbach, 2014, pp. 329-333). A clear focus on managerialism, hierarchization, formalization of structures, and accountability is visible, 
which are characteristics of complete organizations and organizational actorhood (Brunsson \& Sahlin-Andersson, 2000; Krücken \& Meier, 2006). It is shown that faculties can act in an agile way and, behaving more as complete organizations, respond to agility drivers. It is possible for faculties to change and design their organizational structures by responsible employees. So, additional research could consider more effectiveness and efficiency than legitimacy. It can be assumed that the results differ from country to country because the degree of NPM varies, as research has shown (Lange \& Schimank, 2007). NPM is relatively strong e. g. in Great Britain, Australia and the USA. There could be a positive correlation between the development of NPM and organizational actorhood, which may be more pronounced in countries with stronger managerial self-governance. Evaluation in other countries could be an interesting topic for further research.

\section{References}

Blümel, A. (2016). Von der Hochschulverwaltung zum Hochschulmanagement. Wiesbaden: Springer.

Beckert, J. (1999). Agency, Entrepreneurs, and Institutional Change. The Role of Strategic Choice and Institutionalized Practices in Organizations. Organization Studies, 20(5). 777-799.

Braun, D. (1999). New Managerialism and the Governance of Universities in a Comparative Perspective. In D. Braun \& F.-X. Merrien (Eds.), Towards a New Model of Governance for Universities? London: Jessica Kingsley Publishers, 239-261.

Brunsson, N., \& Sahlin-Andersson, K. (2000). Constructing Organizations: The Example of Public Sector Reform, Organization Studies, 21(4), 721-746.

Delucchi, M. (2000). Staking a Claim: The Decoupling of Liberal Arts Mission Statements from Baccalaureate Degrees Awarded in Higher Education. Sociological Inquiry, 70, 157-171.

Christensen, T. (2011). University governance reforms: potential problems of more autonomy? Higher Education, 62(4), 503-517.

Cohen, M. D., March, J. G., \& Olsen, J. P. (1972). A Garbage Can Model of Organizational Choice. Administrative Science Quarterly, 17(1), 1-25.

Corbin, J., \& Strauss, A. (1990). Grounded theory research: Procedures, canons and evaluative criteria, Zeitschrift für Soziologie, 19(6), 418-427.

Döring, N., \& Bortz, J. (2016). Forschungsmethoden und Evaluation in den Sozial- und Humanwissenschaften (5th ed.). Berlin, Heidelberg: Springer.

Elken, M., \& Røsdal, T. (2017). Professional higher education institutions as organizational actors. Tertiary Education and Management, 23(4), 376-387.

Flick, U. (2016). Qualitative Sozialforschung: Eine Einfuihrung (7th ed.). Reinbek bei Hamburg: Rowohlt.

Frese, E. (1992). Organisationsstrukturen, mehrdimensionale. In E. Frese (Ed.): Handwörterbuch der Organisation (3rd ed., 1670-1688), Stuttgart: C.E. Poeschel. 
Glaser, B. G., \& Strauss, A. L. (1975). The discovery of grounded theory: strategies for qualitative research. Chicago: Aldine Publishing Company.

Hüther, O., \& Krücken, G. (2018). Higher education in Germany - recent developments in an international perspective. Cham: Springer.

Krücken, G., \& Meier, F. (2006). Turning the university into an organizational actor. In G. S. Drori, J. W. Meyer, \& H. Hwang (Eds.), Globalization and organization: World society and organizational change (pp. 241-257). Oxford: Oxford University Press.

Krücken, G., \& Röbken, H. (2009). Neo-institutionalistische Hochschulforschung. In S. Koch \& M. Schemmann (Eds.), Neo-Institutionalismus in der Erziehungswissenschaft (pp. 326-346). Wiesbaden: VS.

Lange, S., \& Schimank, U. (2007). Zwischen Konvergenz und Pfadabhängigkeit: New Public Management in den Hochschulsystemen fünf ausgewählter OECD-Länder. In K. Holzinger, H. Jörgens, \& C. Knill (Eds.), Transfer, Diffusion und Konvergenz von Politiken (pp. 231-260). Wiesbaden: VS.

Levy, D. C. (2006). How private higher educations's growth challenges the new institutionalism. In H. D. Meyer \& B. Rowan (Eds.), The new institutionalism in education (pp. 143-162). New York: State University of New York Press.

March, J. G., \& Sutton, R. I. (1997). Organizational Performance as a Dependent Variable. Organization Science, 8(6), 698-706.

Mayring, P. (2015). Qualitative Inhaltsanalyse (12th ed.). Weinheim, Basel: Beltz.

Mayring, P. (2014). Qualitative Content Analysis: Theoretical Foundation, Basic Procedures and Software Solution, SSOAR: Klagenfurt.

Meier, F. (2009). Die Universität als Akteur. Zum institutionellen Wandel der Hochschulorganisation. Wiesbaden: VS Verlag.

Meyer, H. D., \& Rowan, B. (2006). Institutional Analysis and the Study of Education. In H. D. Meyer, \& B. Rowan (Eds.), The new institutionalism in education (pp. 1-14), New York: State University of New York Press.

Meyer, J. W., \& Rowan, B. (1977). Institutionalized Organizations: Formal Structure as Myth and Ceremony. American Journal of Sociology, 83(2), 340-363.

Mintzberg, H. (1983). Structure in Fives. Designing Effective Organizations. Englewood Cliffs, NJ: Prentice-Hall.

Morphew, C. C., \& Hartley, M. (2006). Mission Statements: A Thematic Analysis of Rhetoric Across Institutional Type. The Journal of Higher Education, 77(3), 456-471.

Oliver, C. (1991). Strategic Responses to Institutional Processes. The Academy of Management Review, 16(1), 145-179.

Palvia, P., Leary, D., Mao, E., Midha, V., Pinjani, P., \& Salam, A. F. (2004). Research methodologies in MIS: an update, Communications of the Association for Information Systems, 14(1), 526-542.

Röbken, H. (2004). Inside the „Knowledge Factory“ - Organizational Change in Business Schools from a Neo-Institutional Perspective.Wiesbaden: Deutscher Universitätsverlag.

Scherm, E., \& Pietsch, G. (2007). Organisation. München: Oldenbourg. 
Strübing, J. (2014). Was ist Grounded Theory? In J. Strübing (Ed.), Grounded Theory (3rd ed., pp. 9-35). Wiesbaden: VS.

Vogelsang, K., Steinhüser, M., \& Hoppe, U. (2013). A Qualitative Approach to Examine Technology Acceptance. Proceedings of ICIS 2013, Milan.

Walgenbach, P. (2014). Neoinstitutionalistische Ansätze in der Organisationstheorie. In A. Kieser \& M. Ebers (Eds.), Organisationstheorien (7th ed., pp. 295-345). Stuttgart: Kohlhammer.

Walgenbach, P., \& Meyer, R. (2008). Neoinstitutionalistische Organisationstheorie. Stuttgart: Kohlhammer.

Weick, Karl E. (1976). Educational Organizations as Loosely Coupled Systems. Administrative Science Quarterly, 21(1), 1-19. 